\title{
"I am the Buddha, the Buddha is Me": Concentration Meditation and Esoteric Modern Buddhism in Burma/Myanmar
}

\author{
Niklas Foxeus
}

\begin{abstract}
In postcolonial Burma, two trends within lay Buddhism - largely in tension with one another - developed into large-scale movements. They focused upon different meditation practices, insight meditation and concentration meditation, with the latter also including esoteric lore. An impetus largely shared by the movements was to define an "authentic" Buddhism to serve as the primary vehicle of the quest for individual, local, and national identity. While insight meditation was generally considered Buddhist meditation par excellence, concentration meditation was ascribed a more dubious Buddhist identity. Given this ambiguity, it could be considered rather paradoxical that concentration meditation could be viewed as a source of "authentic" Buddhism.

The aim of this article is to investigate the issue of identity and the paradox of authenticity by examining the concentration meditation practices of one large esoteric congregation and tentatively comparing its practices with those of the insight meditation movement. It will be argued that the movements represented two varieties of so-called modern Buddhism (rationalist modern Buddhism and esoteric modern Buddhism) drawing on different Buddhist imaginaries and representing two main trends that are largely diametrically opposed to one another. They therefore represent two ways of constructing an individual, local, and national identity.
\end{abstract}

\section{Keywords}

Buddhism - Burma/Myanmar - identity - concentration meditation - insight meditation

During the British colonial period in Burma, insight meditation and concentration meditation became associated with two separate soteriological lay Buddhist movements. ${ }^{1}$ Since the late nineteenth century, there has been an increasing tendency to emphasize the relevance for Buddhist laypeople of the supermundane dimension of the highest truths ( $\mathrm{P}$. paramatthasacca), previously only a concern of the elite within the monastic community. ${ }^{2}$ Accordingly, insight meditation (P. vipassanā) and scholastic Abhidhamma were disseminated to the laity

I wish to thank the participants of the seminar held during the fall of 2012 at Stockholm University, especially Per-Arne Berglie, Erik af Edholm, Peter Jackson, and Stefan Larsson, as well as the anonymous reviewers and Gregory D. Alles for their helpful criticisms of this article. The research was funded by the Swedish Research Council (grant number 421-2012-1172).

1 Insight meditation and concentration meditation should, according to the authoritative fifth-century treatise Visuddhimagga by Buddhaghosa, ideally work in tandem in the pursuit of enlightenment and nirvana (see Cousins 1984).

2 In this article, "P." is an abbreviation for Pāli. All foreign words are Burmese, unless otherwise indicated. The term "nirvana" will be used instead of the Pāli nibbāna, since the former has been adopted into English as a loan-word. 
by a number of influential monks. ${ }^{3}$ While insight meditation was regarded as the Buddhist form of meditation par excellence, concentration meditation (P. samatha) was frequently ascribed a more ambiguous Buddhist identity (see Houtman 1990; Pranke 1995). During roughly the same period as insight meditation began to be popularized, an esoteric soteriological path emerged, focusing on concentration meditation combined with esoteric lore (see Pranke 2011; Ferguson and Mendelson 1981). ${ }^{4}$

The development of these two movements was underpinned by an optimistic view of the possibility to make immediate soteriological progress on the path to enlightenment and nirvana, and even to attain nirvana as a Buddhist saint (P. arahant). In pre-colonial Burma, such progress was generally considered impossible because the Buddha's dispensation (P. sāsana) was regarded as being too degenerated, but from the mid-eighteenth century and throughout the nineteenth century, the more optimistic view gradually developed and spread (Pranke 2011; Braun 2008).

In many Asian countries, varieties of so-called modern Buddhism emerged in the nineteenth century onward in response to, in negotiation with, and in opposition to projects of modernization and colonization, shifting socio-economic circumstances, and nation-building projects. These novel constructions and interpretations of Buddhist practice and concepts are complex hybrids combining a number of sources, drawing both on the old and the new, reflecting the interests of those involved, identity politics, and power struggles (see Foxeus forthcoming). While a huge bulk of scholarly literature on insight meditation has emerged in recent decades, varieties of modern Buddhism focusing upon concentration meditation have largely been neglected. I suggest that we refer to the Burmese forms of the two orientations mentioned above as rationalist modern Buddhism and esoteric modern Buddhism, respectively. ${ }^{5}$

A wide range of features characterizing modern forms of Buddhism have been outlined, but this article will especially focus on communities of lay Buddhists who have embarked on the path to enlightenment and nirvana, emphasized the practice of meditation, and expected immediate results. The concomitant "monasticization" of lay roles (see Houtman 1990; Turner 2009) has tended to blur — at least to some extent — the boundaries between the monks and the laity.

Since the colonial period, Buddhism has been perceived as the essence of Burman/Burmese national identity (see Schober 2011). As a nationalist slogan stated, "To be

This partly developed in response to criticism of local, practiced forms of Buddhism by Christian missionaries, etc. It represented a strategy of presenting Buddhism as a rational philosophy and as superior to Western science and Christianity, and of preserving Buddhism under colonialism (Braun 2008:179-181). In 1885, shortly after the whole of Burma was colonized, the scholastic forest monk Ledi Hsayādaw (18461923), who is regarded as the founder of the modern vipassana movement, was instrumental in disseminating insight meditation and scriptural learning (P. pariyatti) among the laity (Braun 2008; Pranke 2011). For more on the history of insight meditation in Burma, see Pranke 2011; Houtman 1990, 1999; Braun 2008.

4 In this article, the adjective "esoteric" is employed to qualify notions and practices intended largely for initiated members. For a discussion of the use of the term "esoteric" with regard to weizzā congregations, see Foxeus 2011:3-10.

5 However, these analytical concepts should not be reified since the corresponding forms of Buddhism are not homogenous but are instead being marked by diversity. What is intended here is a way to single out forms of Buddhism marked by the encounter with modernity, colonization, and so forth. For characterizations of rationalist modern Buddhism, see Lopez 2002; King 2002; Houtman 1990:15-16). 
a Burmese is to be a Buddhist." ${ }^{6}$ That is, Buddhism has been the main medium through which individual, local, and national identity has been forged. Both forms of modern Buddhism addressed the issue of what it means to be a Buddhist - an "authentic" Buddhist — but offered rather different answers. The movements seem to have constructed their respective forms of Buddhism in contradistinction - or even in opposition — to one another: an emphasis on canonical, doctrinal texts versus an emphasis on local traditions, respectively. Given the prevalent view of the dubious nature of concentration meditation, the question inevitably arises how an "authentic" Buddhism could be constructed in esoteric congregations. $^{7}$

The aim of this article is therefore to probe how this "problem" was resolved in one large Burmese esoteric congregation by investigating its strongly ritualized and complex concentration meditation practices. Moreover, some tentative comparisons will be made with the insight meditation movement, thereby highlighting the main points of divergence of the two movements and investigating their socio-political ramifications. The esoteric congregation's concentration meditation techniques might appear to be surprisingly similar to so-called Tantric visualization meditation, and since this phenomenon is rather unknown in the context of Theravāda Buddhist traditions, the techniques will be discussed in some detail. $^{8}$

\section{Two Modern Buddhist Movements in Postcolonial Burma}

It was not until the late colonial and early postcolonial period that - in a "meditational revolution" (Brohm 1957:341) — the two forms of modern lay Buddhism developed into large-scale movements, both equally nationalist. ${ }^{9}$ Their emergence intersected with an early postcolonial Buddhist revitalization in which the state, led by Prime Minister $\mathrm{U} \mathrm{Nu}$, was involved (see Brohm 1957). In the post-independence period, starting in 1948, Burmese society - like many other countries in Asia - was characterized by a "modern crisis of authority" (Keyes, Hardacre, and Kendall 1994). The religious currents in these years responded not only to the state's projects of modernization and nation-building, but also to the ongoing impact of the previous colonial period. Such vestiges of colonialism were frequently viewed as a threat to the indigenous culture and Buddhism. Questioning the traditional certainties and religious authorities, many Buddhists set out on a quest for an "authentic" Buddhism purged of the perceived contamination of foreign or traditional accretions (see Houtman 1990; Foxeus 2011). This renewed interest in religion as a vehicle for reasserting national and individual identity was part of the general re-enchantment of Asia

6 This nationalist slogan was allegedly coined by the Young Men's Buddhist Association (YMBA) in the early twentieth century (Schober 2011:66).

7 The esoteric congregations have been a popular subject of criticism and ridicule, especially among representatives of rationalist modern Buddhism, and concentration meditation has typically been regarded as non- or pre-Buddhist (see Houtman 1990:176-194).

8 A comparable concentration meditation movement is Dhammakāya in Thailand (see Mackenzie 2007). The term "Theravāda" was rarely used in pre-modern South and Southeast Asia. It became popular after 1950 in these regions and was linked to issues of Buddhist and national identity (see Perreira 2012; Kirichenko 2009). Although it could be argued that the term should be avoided, in this article it is used as a familiar shorthand term for varieties of Buddhism related to the legacy of Pāli texts (canonical, commentarial, and local).

9 Although some monks were affiliated with these movements, the majority of the practitioners were laypeople. 
This is the version of the article that was accepted for publication. It was published in 2016 in Numen 63: 411-445.

in the period following World War II (see Keyes, Hardacre, and Kendall 1994; Schober 1995).

The relations between the two movements, and between the concentration meditation movement and the state, have been marked by tensions. That should draw our attention to their involvement in a wider cultural field of power relations in which there is a "mutual imbrication of religion, culture and power" (King 2002:207-218]; see also Lincoln 2006:7879). ${ }^{10}$ While insight meditation was a prestigious national export commodity, a source of national pride, and was institutionalized and supported by both parliamentary and military post-independence governments (see Jordt 2007), ${ }^{11}$ the esoteric congregations were regarded with disfavor. The semi-military, socialist government led by General Ne Win even sought to suppress these congregations from the early1980s onward (Tosa 1996; Pranke 2011; Foxeus 2011, forthcoming). ${ }^{12}$

A lay Buddhist mass movement emerged, which Ingrid Jordt (2007) has referred to as the "New Laity."13 This movement tended to be anti-ritualistic, rationalist, and anti-traditionalist. It emphasized empiricism and the practice of a simplified version of insight meditation that was often understood as being compatible with science (see King 1990; Brohm 1957). In the idiom of "enlightenment in this very life" (Jordt 2001:99), its practitioners sought to purify their minds in order to attain at least the lower levels of enlightenment along the path to nirvana and Buddhist sainthood (see Jordt 2007; Brohm 1957). ${ }^{14}$ This movement viewed insight meditation as "ultra Buddhist and ultra-Burmese" (Houtman 1990:16).

In this period, a large number of initiatory, hierarchical, and semi-secret esoteric congregations were founded. They emphasized supernatural sources of authority (accomplished esoteric masters) and charismatic authority (founders of esoteric congregations). Their path of esoteric knowledge (weizzā-lan) represented an alternative soteriology, with a ritualistic mode of practice. The practitioner typically sought - in the here and now — to become a mundane accomplished esoteric master (weizzädhour; P. vijjädhara) who has attained success in mundane esoteric arts combined with concentration

10 For more on the tensions between the two movements, see Houtman 1990; Pranke 2011; Patton 2012.

11 In 1949 Prime Minister U Nu was involved in establishing what is still Burma's largest meditation center. It was headed by the monk Mahāsī Hsayādaw (1904-1982), and his method of insight meditation was recognized as orthodox by the government under General Ne Win in the 1980s (Jordt 2007:52).

12 One reason for the suspicion with which the esoteric congregations were treated by the state is probably that they represented a quest for power and were therefore a potential source of social unrest. Although the state sought to suppress these esoteric congregations, many politicians, soldiers, and military officers have taken a personal interest in them (see Houtman 1999:332; Pranke 2011; Mendelson 1960:116; Foxeus 2011, forthcoming).

13 Although the insight meditation movement was by no means monolithic but, rather, was marked by diversity, conflicts, and disagreements, especially regarding the status to be accorded to concentration meditation, the identity of the various schools as representing insight meditation was not in doubt (see Houtman 1990:187-189). Similarly, insight meditation was — to various degrees — incorporated into the practices of some esoteric congregations, although concentration meditation remained their main practice. Since the superior value of vipassanā meditation was undisputed within both movements, the esoteric congregations therefore sought to appropriate it as well, primarily as a source of social prestige and authority, and as a way to escape social criticism.

14 Of the four stages of enlightenment and nirvana (P. sotāpanna, sakadāgāmin, anāgamin, and arahant), the practitioners of insight meditation typically seek to attain at least the first one in their present existence. Promising quick results for those practicing his method, Mahāsī Hsayādaw estimated it would take an average of two months to attain the first stage, but that some may attain it after only one or two weeks (Jordt 2007:33; Mahāsi Hsayādaw 1990:30; Brohm 1957), something that seems to be suitable for a busy middle class. 
meditation and Buddhist morality (P. sīla). Having acquired supernormal powers and undergone an ontological transmutation (htwek-yap-pauk), he (it is invariably a male) becomes semi-immortal. Transcending the round of rebirths, the esoteric master is able to remain - as in a perpetual liminal phase - in one and the same existence until he attains enlightenment and nirvana as a Buddhist saint or a buddha in the remote future. ${ }^{15}$

This movement sought to creatively refashion and synthesize a range of local practices and notions. While being innovative and highly hybrid, they were to varying degrees faithful to the indigenous and "classical" Buddhist traditions. While the insight meditation movement ascribed primary authority to a selection of texts from the Pāli Canon, thereby stripping the putatively authentic Buddhism of traditional accretions, the esoteric movement tended to reaffirm local sources of authority and the Pāli commentarial tradition.

Furthermore, the soteriological optimism that had evolved since the mid-eighteenth century culminated in the early post-independence period and was articulated in the novel concept of wimoutti-yuga-khayt, the "Liberation Era," which would begin in the second half of the Buddhist era, starting in 1956-1957 (see Foxeus 2011; Houtman 1990; Pranke 2011). Some interpreted it as an era in which it would be easy to attain weizzāahood whereas others expected it to be easier to make spiritual progress by means of insight meditation (Foxeus 2011).

\section{Two Modalities of Practice: The Jātaka/Buddhavaṃsa Mode and the Sutta Mode}

The two movements emphasize different modalities of Buddhist practice: the Jātaka/Buddhavamsa mode (hereafter Jātaka mode) favored in many esoteric congregations, and the Sutta mode predominant in the vipassana movement. These modes of practice serve as models to be emulated and are imagined in rather different worlds drawing on the Pāli textual legacy, local vernacular texts, rituals, oral traditions, sermons, and the material dimension of Burmese Buddhism. ${ }^{16}$ The Jätaka mode underscores the lineage of previous and future buddhas and Gotama Buddha as a bodhisatta in his former existences - his vow as the hermit Sumedha to attain buddhahood under Buddha Dīpankara, as well as his fulfilling of perfections (P. pāramī) through heroic acts of utmost self-abnegation for the sake of others throughout innumerable existences before finally attaining buddhahood. In this mode, the Buddha serves as model of and for the practitioners to emulate. This mode is more narrative and stresses cyclical time (a series of buddhas), and its gaze is turned toward the remote future. Historically, this mode has been associated with the Burmese kings and has constituted an important feature of a royal Buddhist imaginary (cf. Gravers 2012; see more below). In several esoteric congregations, that imaginary has been reshaped and inflected by esoteric notions (see above), thereby constituting a royal-esoteric Buddhist imaginary.

15 For more on the esoteric path, see Ferguson and Mendelson 1981; Pranke 2011; Rozenberg 2010a, 2010b; Foxeus 2011.

16 The Jātaka mode is ultimately derived from Pāli texts such as the Jātakas, Buddhavamsa, and the Nidānakathā, i.e., the introduction to the birth-stories (cf. Schober 1988); the Sutta mode is ultimately derived from what are presented as being the Buddha's sermons in the Sutta Pitaka. In general, Burmese Buddhists are aware of these two distinct modes and likewise models to emulate and see them as representing two ways of Buddhist practice and their fruits. Following Peter Skilling (2012), these modes might be inflected in various ways in multiple, fluctuating, and local Buddhist imaginaries. In contrast to Steven Collins' concept of a "Pali imaginaire" (2006:40-117), these local imaginaries are neither stable nor cohesive. For a criticism of Collins' concept, see Skilling 2012. 
The Sutta mode tends to be more narrow and emphasizes the pristine community of Gotama Buddha's early disciples (P. sāvaka), both lay and monastic, who easily achieved enlightenment and nirvana in one lifetime under the guidance of the Buddha. In this mode, the early disciples serve as a model of and for the practitioners, and the Buddha is merely the teacher, represented - in the main - by monastic meditation teachers. Its temporal mode is linear (Gotama Buddha's final existence), and it therefore stresses the practitioners' present existence. Buddhist practice is thus envisioned in what could be called a Buddhist apostolic imaginary (cf. Jordt 2007:25; Pranke 2011). In the insight meditation movement, this imaginary has been shaped by what largely is a middle-class ideology.

\section{Identity, Power, and Empowerment: Two Political Models}

While there seems to be a kind of elective affinity between the modern simplified version of insight meditation and the lifestyle and values of the urban middle classes, informed to some extent by colonial modernity and post-Enlightenment rationality (see Gombrich and Obeyesekere 1990:202-240; Brohm 1957:340-352), the esoteric path was more ambiguous. The esoteric congregations attracted people from all social strata, including business people, workers, civil servants, politicians, military officers, and peasants. Most of the esoteric congregations were founded in urban centers, especially Yangon. ${ }^{17}$ Following S. N. Eisenstadt (2000) and his concept of "multiple modernities," I suggest that we view these two movements as representing local Burmese varieties of modernity.

In the modern era, as Gustaaf Houtman (1999) argues, the two meditation techniques have become associated with two distinct political models: (royal) autocracy and democracy, which are manifested in the military dictatorships of Burma and the democratic opposition, respectively. While concentration meditation is associated with traditional Buddhist notions of power, control, and authority to command (P. $\bar{a} n \bar{a})$, emphasizing a hierarchical identity and a corporative social organization, insight meditation is associated with individualism, influence ( $a w z a$ ), and democracy (Houtman 1999; see also Gravers 1996). While the former is "particularistic" or "cultural primordialist," the latter represents humanism and universalism (Gravers 1996, 2012; cf. Eisenstadt 2000:10). ${ }^{18}$ This discussion is pertinent for the present article because the autocratic model has strongly shaped the ariy $\bar{a}$-weizz $\bar{a}$ organization's discourses on power and authority. Given the social base of this congregation (see below), I suggest, following Victor Turner, that its hierarchical structure - its liminal pseudo-hierarchy - and the authoritarian model have served as a template for status reversals for people of lower strata, similar, for instance, to cargo cults in Melanesia (Turner 1977:188-194). ${ }^{19}$ That is, the socio-political pattern of the dominant strata in society, I argue,

17 Initially, insight meditation was popular among the urban middle classes in Burma. Today it is not confined to a particular social stratum but attracts people of all ages and occupational backgrounds, from urban areas and countryside alike (see Brohm 1957:340-352; Jordt 2007; Pranke 2011). Hence, what originally was part of a middle-class ideology later spread to other social groups.

18 Houtman has been criticized for reifying this polarized model and for viewing it as corresponding to an ideological and social polarity in society, that is, between the military government (SLORC/SPDC, 19882011) and the democratic opposition, especially the National League for Democracy led by Aung San Suu Kyi. However, the social reality did not support such a divide (see Jordt 2007; Rozenberg 2009).

19 Lower strata tend to emphasize hierarchy, while upper strata emphasize egalitarian communitas (see Turner 1977:188-197). 
This is the version of the article that was accepted for publication. It was published in 2016 in Numen 63: 411-445.

is mimicked by lower orders to provide them, among other reasons, with a sense of empowerment and to serve as a source of identity. ${ }^{20}$

\section{The Ariyā-Weizzā Organization and the Noble Esoteric Path: "Authentic" Soteriological Buddhism}

The ariy $\bar{a}$-weizz $\bar{a}$ organization was founded by a layman — a former military officer — in the late 1940s and is one of the so-called royal esoteric congregations that emerged in the early postcolonial period. ${ }^{21}$ It was founded in Taungoo in Lower Burma but its center was soon moved to Yangon. Many, perhaps the majority, of the members live in rural areas. ${ }^{22}$ The members regard the founder as a Buddhist world emperor, a future Buddha, and an accomplished esoteric master. ${ }^{23}$ The social organization of the congregation is hierarchical, with ordinary members and local leaders subordinated to the founder. The congregation seeks to restore the royal Buddhism of pre-colonial Burma and represents an attempt, with nationalist overtones, to grapple with issues of postcolonial identity. Accordingly, the members are ascribed a royal identity and are understood to belong to a royal family. The congregation's visualization techniques represent a full-fledged and systematized "Theravāda" Buddhist bodhisattayāna, a "vehicle of future buddhas.,"24

As indicated above, the soteriological model that many Burmese kings and some esoteric congregations have emulated is the extended biography of Gotama Buddha. In Burma, as well as in other countries in mainland Southeast Asia, the bodhisatta path often served as an ideology that provided kings with legitimacy. Like Gotama Buddha, who is depicted as having become a world emperor (P. cakkavattin) several times in previous existences, the Burmese kings were frequently associated with this ideal or even claimed such status. ${ }^{25}$ Similarly, the ariy $\bar{a}$-weizz $\bar{a}$ organization's self-image is one of a moral community of bodhisattas, who will become world emperors on their path to buddhahood. Like the Burmese kings, the members seek to save the beings and make vows to propagate and defend Buddhism. While the insight meditation movement represented a democratization of

20 For other explanations of the status reversals, see Turner 1977:200-203.

21 I conducted fieldwork in Burma periodically from 2005-2008, both in Upper and Lower Burma. In this article, all my informants are rendered anonymous. The name "the ariy $\bar{a}-w e i z z \bar{a}$ organization" is used as a sobriquet. One of the names of the congregation is Ariyā-Weizzā Manaw-Mayeiddhi Weizzādhour Pyinnya Khwin Gyī, the "Great Sphere of Knowledge of the Accomplished Esoteric Masters, who have Supernormal Mind-Power and Noble Esoteric Knowledge." During military rule, the congregation changed its name a number of times because of the political situation. The founder was frequently arrested.

22 According to several leaders, they have mainly engaged in proselytizing among peasants in the countryside from the $1950 \mathrm{~s}$ up to the $1980 \mathrm{~s}$. As a local leader explained in 2008, the congregation has been most successful with these activities in rural areas because in the cities they had to compete with the more popular insight meditation centers. After the government's crackdown on esoteric groups in the 1980s, the congregation's active proselytizing came to an end. Many of the leaders seem to belong to the lower-middle classes. Although there are some monks in the congregation, the overwhelming majority are laypeople.

23 The founder was held to be an "incarnation" of a famous anti-colonial figure called Sekyā Min (P. cakkavattin), the "world emperor," and is thought to be the future Rāma Buddha. He passed away in 1999, but the members believe that rather than dying he underwent a transmutation and left for a hidden abode. For more on Sekyā Min, see Ferguson and Mendelson 1981; Sarkisyanz 1965; Foxeus 2011, 2012, forthcoming.

24 The word bodhisattvayāna is an old Indian designation for what was later known as "Mahāyāna" Buddhism (see Hirakawa 1993:258-259). For a general discussion of the bodhisatta ideal in Theravāda Buddhism, see Samuels 1997.

25 For more on this model for the kings, see Koenig 1990; Lieberman 1984. For more on Gotama Buddha's path to buddhahood as a model for esoteric congregations, see Schober 1988; Pranke 2011; Foxeus 2011. 

63: 411-445.

enlightenment on the path to arahanthood (Houtman 1999:8), some esoteric congregations represented a democratization of bodhisattahood. In the ariyā-weizzā organization, anyone can become a member and make bodhisatta vows.

The tenets and practices of the ariy $\bar{a}$-weizz $\bar{a}$ organization are claimed to represent "real" or "authentic" Buddhism (ta-keh-bouddha-bhatthā) as distinguished from traditional or inherited Buddhism (mi-you-hpalā-bouddha-bhāthāa). Some leaders described the latter as a rather simple form of practice comprised of merit-making (giving alms-food to the monks, etc.) and the observance of some Buddhist precepts. While that represented a passive form of Buddhist practice, both the esoteric congregation and the insight meditation movement claimed to represent a more active form of practice requiring effort and commitment (see Houtman 1990; Foxeus 2011). The congregation's "authentic" form of Buddhism is said to be derived from a supernatural source of authority, namely, the esoteric master U Dhammasāri and his Golden Book. ${ }^{26}$ As in several new Buddhist movements in Southeast Asia (see Schober 1995), there is an emphasis on moral discipline. The members must vow to observe the rather austere "noble discipline" (P. ariya-sikkha $)$, an essential element of which is the vow to seek to fulfill perfections to attain final release from the round of rebirths in one of five modalities of enlightenment. ${ }^{27}$ In contrast to pre-colonial Buddhism, but like many other forms of modern Buddhism, the ariy $\bar{a}$-weizza organization is "doctrinal," framing its tenets in abhidhamma-style terminology. ${ }^{28}$ Several leaders even insisted I must learn Abhidhamma thoroughly before learning and practicing their meditation techniques. ${ }^{29}$ Like the majority of traditional religions, the congregation represents a maximalist form of religion (Lincoln (2006:5-8)), that is, a religion that permeates all aspects of daily life and the socio-political order, and it is in line with the Burmese pre-colonial notion of the Buddha's allencompassing sāsana. ${ }^{30}$

\section{The Ariya Discourse}

In contemporary Burma, a fundamental distinction is frequently made between a mundane ( $\mathrm{P}$. lokiya) and supermundane (P. lokuttara) orientation of Buddhist practice. In esoteric

26 U Dhammasāri is regarded as a monk and likewise an accomplished esoteric master, and he is known in other congregations as well. Hence, just like the insight meditation movement that relied on the textual authority of the modern lineages of monks, the ariy $\bar{a}$-weizza $\bar{a}$ organization did not bypass monastic authority.

27 At the initiation rituals, etc., the members make vows to observe the noble discipline for the rest of their lives as follows: 1) to observe the five Buddhist precepts (P. sīla); 2) to take refuge in the Three Jewels; 3) to pay respect to the Five Eternities (Buddha, Dhamma, Sangha, teachers, and parents); 4) to support and defend the Buddha's sāsana and save all beings; and 5) to seek to attain one of five kinds of enlightenment (P. bodhi) and nirvana as a buddha or a saint. The majority of the male members have made bodhisatta vows to attain enlightenment as a buddha.

28 Ledi Hsayādaw promoted a doctrinal form of Buddhism for the Buddhist laity (see Braun 2008; Kirichenko 2009) - a common characteristic of modern Buddhism.

29 Likewise, Ledi Hsayādaw and his disciples required practitioners first to learn Abhidhamma before practicing insight meditation (see Braun 2008, chapter 6). His emphasis on doctrines and scriptural learning contrasts with Mahāsī Hsayādaw's approach, which regards such learning as an obstacle to progress in insight meditation. The meditation technique of the latter has remained one of the most popular in postcolonial Burma (see Braun 2008:396-397; Houtman 1990; Jordt 2007).

30 This was a hierarchical system in which religious and social identities were inseparable (see Kirichenko 2009). Being based on practice rather than doctrines, sāsana refers to "Buddhism" as grounded and embodied in society: monks, texts, pagodas, monasteries, relics, Buddhist learning and practice, etc. (see Foxeus forthcoming). 
congregations, the former is mainly composed of the "Gandhāra lore" (P. gandhāri vijjā), which in Burma is usually comprised of alchemy, esoteric squares, syllabic figures, and medicine. ${ }^{31}$ In contrast to the majority of the esoteric congregations, the ariy $\bar{a}$-weizz $\bar{a}$ organization is presented as a supermundane congregation, and its esoteric tenets and practices - by which weizzāhood, as well as arahanthood and buddhahood, can be attained - are qualified as ariya (P. ariya) "noble," "pure." In contemporary Burma, the concept of ariya is linked to the supermundane dimension of Buddhism and is at the heart of rationalist modern Buddhism and the vipassana movement. Framed by abhidhamma concepts, this ariya dimension - which I will refer to as the "ariya discourse" — is usually interpreted as a set of doctrines, especially the Noble Eightfold Path, the Four Noble Truths, and the Three Characteristics of existence (impermanence, suffering, and non-self), as well as the practice of meditation. The latter tend to be exclusively understood as insight meditation, which can be practiced at the numerous meditation centers all over the country. This path is what Ledi Hsayādaw (1985:293) refers to as "ariy $\bar{a}$-weizza $\bar{a}$," the "noble wisdom," in his influential Vijjāmagga Dipanī, "Explanation of the Path to Wisdom."

However, the books of the ariy $\bar{a}$-weizza $\bar{a}$ organization, although they incorporate the ariya discourse, display a wider and more ambiguous connotation of the word ariya. ${ }^{32}$ In this way the ariy $\bar{a}$-weizz $\bar{a}$ organization - as do other supermundane esoteric congregations - seeks to align itself with the insight meditation movement in the quest for authority and legitimacy. Qualifying its tenets and practices as "ariy $\vec{a}$ " serves as a discursive strategy to present the congregation as supermundane and orthodox, and it is reinforced by the pervasive presence of technical abhidhamma terminology in its books. Moreover, the ariya discourse sometimes serves as a criticism of what are perceived as non-Buddhist elements, such as the Gandhāra practices. This discourse therefore posits the congregation as being superior to the majority of the other esoteric congregations, which are typically concerned with mundane Gandhāra lore. However, some Gandhära congregations incorporate the ariya discourse to some degree into their manuals (cf. Pranke 1995). Thus, there are tensions not only between the insight meditation movement and the esoteric congregations but also between the esoteric congregations. ${ }^{33}$

\section{The Esoteric Version of the Recollection of the Buddha: Visualizing and Becoming the Buddha}

Although the visualization techniques and other aspects of the ariy $\bar{a}$-weizz $\bar{a}$ organization could be regarded as a rather extreme example, many features of its practices and notions are

31 For more on these notions, see Ledi Hsayādaw 1985:291; Awbhāthā Biwuntha 1955:166.

32 The congregation's practices are qualified as such because they are stated to be "Buddhist" soteriological practices. Since they are designed for both mundane and supermundane attainments and inflected by its royal-esoteric imaginary, I have translated the phrase "ariy $\bar{a}$-weizz $\bar{a}$ " as "noble esoteric wisdom" to capture this extended use.

33 In its more or less explicit criticism of the Gandhāra lore, the ariy $\bar{a}$-weizzā organization sides with many practitioners of insight meditation, who disparage these practices as being non-Buddhist (see Houtman 1990:186; Patton 2012). Besides the ariy $\bar{a}-w e i z z \bar{a}$ organization, the most prominent example of a supermundane esoteric congregation in contemporary Burma is the Manaw-Mayeiddhi Weizzādhour Gain, the "Congregation of the Accomplished Esoteric Masters, who have Supernormal Mind-Power," which was founded by Pyiloun Khyanthā Hsayā Kyaw Gȳ̄ in the 1920s (see Foxeus 2011). This congregation also employs the ariya discourse to buttress its claims of superiority over Gandhāra congregations (see Tosa 1996). 

63: 411-445.

shared by other esoteric congregations and the like. Using this congregation as an example could therefore help to highlight some of the basic differences vis-à-vis the insight meditation movement.

The congregation's main practices are its own visualization techniques referred to as ariy $\bar{a}$-weizzā-patipāt, the "practices of noble esoteric knowledge," which consist of five main meditation practices and three auxiliary ones. ${ }^{34}$ This article will only discuss the most popular of the main practices, namely, an esoteric version of the "recollection of the Buddha" (P. buddhānussati-kammatthāna) $)^{35}$ and two auxiliary ones. Members are instructed to engage in certain meditation practices every morning and evening, and the recollection of the Buddha should be performed in the evenings. In a modern fashion, initiated members are expected to take a ten-day course to learn the group's basic tenets and practices, along with the visualization techniques. In those classes, the teacher uses a blackboard and the students are provided with course books. In contrast to the insight meditation movement, the congregation has no separate meditation centers.

My sources consist of the congregation's books, interviews with leaders and ordinary members, and video recordings that I made in 2007 with a local leader who performed and explained the intricate meditation program. ${ }^{36}$ The main textual sources I have used are the Ariyā-weizzā-patipāt Dhät-tek-sin-kyan (1997), the "Treatise on the Development of Dhāt and the Practice of Noble Esoteric Knowledge," written by the founder, and the Shin-tan-teksin Thin-tan-gyi (1979 [1341 M.E.]), "The Great Course on Developing Clarity" (henceforth the "course book"), written by a local leader. The books and the leaders present an "official discourse" that prescribes a lengthy normative procedure for the practice. However, as the leader admitted, ordinary members usually practice a simplified version. The complicated pattern of the systematized ritual program represents the very opposite of the simplified practice in contemporary insight meditation, and some of its ritual procedures are similar to premodern meditation practice in Thailand (cf. Swearer 1995).

The recollection of the Buddha is part of Buddhist devotionalism, which has characterized Buddhist traditions from their inception (see Gokhale 1981). The most popular of the recollections is the triptych Buddha, Dhamma, and Sangha, which likewise is the main object of saddhā. In my Burmese sources, the latter term is usually glossed as youn-khyi-hmu, which refers to a devotional mode of trust, reliance, dependence, veneration, and respect rather than doctrinal commitment (cf. Rozenberg 2010b). ${ }^{38}$ The recollection of the Buddha, including the contemplation of his nine virtues, is very popular in contemporary Burma. Many Burmese

34 All but two of these altogether eight practices are visualization techniques (vipassanā is included but deemphasized by the congregation). The word pațipāt is an abbreviation of the Pāli word patipatti, "practice," which in pre-colonial Burma usually referred to the monks' observance of the disciplinary rules of the Vinaya, but later - in the modern period - came to be understood as a synonym of meditation (see Houtman 1990:79; Kirichenko 2009). According to the congregation, to attain sainthood and buddhahood it is also necessary to practice insight meditation, at least in the final stages.

35 The classic version of this meditation practice is to be found in Buddhaghosa's Visuddhimagga.

36 I am fully aware of the problem of "authenticity" that besets such arrangements as the video recordings, and I have therefore also relied on books and interviews with several local leaders, ordinary members, and monks.

37 M.E. refers to Myanmar Era.

38 In a number of dictionaries, saddhā is translated as "faith" (see Rhys Davids and Stede 1979:675). Following Malcolm Ruel (2008), I think it is advisable — in cross-cultural translation — to try to avoid the word "belief" (as well as its synonym, "faith") due to its Protestant Christian connotations. When the word is transposed to other contexts, such semantic dimensions can create false assumptions and "shadow fallacies" (Ruel 2008:107-108). 

63: 411-445.

people count beads on a rosary while reciting these virtues as mantras to acquire merit, supernormal powers, or worldly success in their lives. This simple local practice is reckoned as concentration meditation. By contrast, the ariy $\bar{a}$-weizz $\bar{a}$ organization's techniques are systematized and framed with technical abhidhamma terminology, comparable in style to Buddhaghosa's fifth-century meditation treatise Visuddhimagga, "The Path of Purity." But, in contrast to the latter, it takes the meditation sequences a step further and does not treat the Buddha as only an object of devotion.

While contemporary practitioners of insight meditation have been regarded as representing a monasticization of the laity, the ariy $\bar{a}$-weizz $\bar{a}$ organization's practices represent the combined roles of forest ascetics and kings. ${ }^{39}$ The latter could therefore be characterized as a monasticization of lay Buddhists in a royal mode. Both movements view the forest ascetic/monk as the ideal, probably because meditation was primarily expected to be practiced by forest monks in the premodern period (see Kirichenko 2009). Although the majority of the practitioners within the insight meditation movement do not practice in the woods, paintings of forests can sometimes be found on the walls of meditation centers as a reminder of the ideal (see Houtman 1990:18). However, the ideal tends to be taken more seriously by practitioners on the esoteric path. For instance, the ariy $\bar{a}-w e i z z \bar{a}$ organization instructs the members to practice in the woods, mountains, or caves laden with potency, where an esoteric master has attained success, or in powerful pagodas built by kings. ${ }^{40}$ In the congregation's books, there is a vocabulary associated with forest monks, and the practitioners should — as a way of emulating the Buddha — ideally perform severe meditation practice for a forty-nine-day period. Before beginning the practice, vows to observe vegetarianism and the nine Buddhist precepts should be made. ${ }^{41}$

In contrast to the anti-ritualistic insight meditation movement, the congregation's meditation practice includes a complex set of ritual preparatory procedures that should be performed. For instance, the yogi should present offerings to the Three Jewels, the Five Eternities, Shin Upagout, the accomplished esoteric masters, and the gods. ${ }^{42}$ A long series of texts should be recited, a protective boundary around the meditation area established,

39 In Burmese tradition, the forest ascetics mainly consist of forest monks and hermits (yathay, derived from the Sanskrit rssi). The latter are rather similar to monks, but observe fewer precepts, and wear a brown robe and distinctive headgear (daukhyā). In the ariyā-weizzā organization's manuals, the practitioners of meditation are referred to as yogis (yawgī), as in the insight meditation movement. Practitioners on the esoteric path often wear brown robes and have vowed to observe a set of Buddhist precepts.

40 One local leader explained that - mainly in the 1970s - he had practiced in the forests, for instance, at Hpo Win Hill where Hpo Win allegedly underwent transmutation and became an accomplished esoteric master during the Pagan Era (1044-1287).

41 This practice is called the "ascetic practice of the noble lineage" (ariya-wuntha-dhutin-akyin) and is prescribed in one of the founder's books (Ariyā-weizzā-pațipāt Dhät-tek-sin-kyan (1997:196-200). The word dhutin is derived from the Pāli dhutanga, which refers to the ascetic practices of a forest monk, and the phrase ariyavamsa can refer to the four "noble usages" of a monk (see Nyanatiloka 2004: 25, 58; see also Awbhāthā Bhiwuntha 1955:47-48). The number forty-nine corresponds to the number of days Gotama Buddha spent at Bodh Gaya after having attained enlightenment and buddhahood and therefore implies an emulation of his paradigmatic success. For a comparison of esoteric practitioners with forest monks, see Schober 1989.

42 According to the local leader, these offerings should be made as a preparation for the meditation practice, and they serve to fulfill the perfection of giving (P. dāna-pāram $\bar{\imath}$ ). However, in the ritual manuals, there are no prescriptions regarding such offerings. The cult of Shin Upagout (P. Upagutta; Sanskrit: Upagupta) is a Burmese remnant of North Indian Sanskrit Buddhism. In Burmese Buddhism, he is generally invoked for protection of Buddhist ceremonies. 
resolutions made, and a set of truth declarations that wish for mundane and supermundane results performed. ${ }^{43}$ Again, in contrast to the insight meditation movement, which tend to disparage cults of supernatural beings (see Houtman 1990), the esoteric movement strongly emphasizes the cult of gods and semi-immortal esoteric masters. ${ }^{44}$ Accordingly, these beings are invoked at several points throughout the practice to witness truth declarations, protect the boundary, and come and give instructions, protection, and help in the practice that leads to supernormal powers and wisdom.

In line with the devotional, submissive stance of this practice, trust in the Buddha is emphasized, and some passages in the manuals even seem to assume that he is present. ${ }^{45}$ For instance, the yogis should recite a text in which they declare that, as disciples of the Buddha, they sacrifice (sun-hlü) their body and mind to the Buddha as an act of ritual devotion (P. pujā). Furthermore, the yogis should ask the Buddha to rescue them out of pity from the round of rebirths and give them the "meditation object of the recollection of the Buddha.",46 Another aspect of devotionalism is the contemplation of the nine virtues of the Buddha. According to a ritual manual, the yogis should recite and contemplate these virtues and conclude by declaring that they, realizing that the exalted Buddha is endowed with these virtues, pay obeisance (shikho) to him as an act of veneration and respect, kneeling, with their hands and forehead touching the ground.

Rosaries, the hallmark of concentration meditation in Burma, are not allowed at insight meditation centers (Houtman 1990:187). Similarly, rosaries should not be used by members of the ariy $\bar{a}$-weizz $\bar{a}$ organization, probably because the congregation seeks to distinguish its practices from traditional Burmese Buddhism and at the same time wishes to align itself more closely with the insight meditation movement and textual Buddhism.

\section{"I am the Buddha, the Buddha is Me"47}

In phenomenological terms, the supermundane insight meditation and the mundane concentration meditation are diametrically opposed to one another. The former promotes a

43 Traditional devotional texts such as the Awgatha (P. okāsa) and the refuge to the Three Jewels should be recited (cf. Spiro 1982:209-214). The truth declaration is generally known as sacca-kiriya, "act of truth," in Theravāda traditions and is expected to bring about miraculous results.

44 While supermundane as well as many mundane congregations tend to exclude the cult of lower nats, "spirits" (the 37 Lords, etc.) but incorporate the Buddhist gods (P. deva) known from the Pāli texts, some mundane Gandhāra congregations include both (see Tosa 1996; Foxeus 2011). For more on the nats, see Spiro 1996.

45 In Ariyā-weizzā-patipāt Dhāt-tek-sin-kyan (1997:27), the Pāli word saddhā is glossed as trust/confidence (youn-khyi-khyin), respect (kyi-nyou-khyin), enthusiasm (htek-than-khyin), and being eager and emotional (zaw-seit-than) towards the Buddha.

46 Besides the fact that some Burmese people regard the Buddha as still alive in some sense (Spiro 1982:148; King 1990:172-179; see also Gombrich 1998), there is an ambiguity here. According to the manuals, the yogi should visualize the Buddha as seated in front of him or her before the preparations are made (making vows, reciting texts, etc.). According to the local leader, the visualizations should be made after these preparations. In the former case, the yogi actually performs the preparatory rituals before the Buddha (as visualized), which fits into the ritual program's general orientation of making the Buddha alive and present. In the latter case, the discourse on the Buddha's presence could be understood in terms of what Gustavo Benavides (2010) has referred to as the "as if" nature of many religious rituals or the "suspension of disbelief” discussed by Peter Jackson (2012).

47 The style and tenor of the ariy $\bar{a}-w e i z z \bar{a}$ organization's visualization practices are rather similar to Tantric Buddhism and Hinduism, and to François Bizot's findings in Cambodia, Laos, and Thailand (see Crosby 2000). 
passive, empirical, and observational mode, the purpose of which is to acquire experiential knowledge of phenomena in terms of a non-conceptual, intuitive insight into how things really are (P. yathäbhütam), that is, impermanent, suffering, and non-self. ${ }^{48}$ The familiar world is thereby deconstructed, culminating in an "irrevocable epistemic break" (Jordt 2007:61), leading to enlightenment and nirvana in the here and now. The aim of concentration meditation, by contrast, is to create and control images and use them for instrumental purposes. It seeks to construct worlds, and, ultimately, to control the external world by means of the supernormal powers acquired from this practice (see Houtman 1990:176-185). While insight meditation aims at complete release from the round of rebirths in the present existence (or in the immediately following ones), esoteric concentration meditation aims to control the rebirth process or to effectuate a transmutation by which the practitioner leaves the rebirth cycle to remain in a liminal state.

Accordingly, a pervasive feature of the esoteric congregation's visualization techniques is the aim of creating and controlling images and controlling the external world. The congregation's visualization techniques oscillate between devotionalism (submissive behavior towards a superior authority) and authoritarianism - two sides of the same coin within the framework of a hierarchical cosmology. The recollection of the Buddha is divided into six stages through which the yogi can gradually and temporarily transform into the Buddha. The focus is on the moment of the Buddha's achievement of enlightenment and nirvana. Unlike the insight meditation movement, which de-emphasizes miracles, the yogi should imagine how the Buddha performs the famous twin miracle (P. yamaka-patihāriya), in which fire and water flow alternately from the upper and lower parts of his body, and radiance of six colors emanates from his body, pulsating concurrently with his heartbeat and scattering throughout the entire universe. ${ }^{49}$

In the first stage, the living Buddha is visualized as seated on his throne beneath the bodhi tree while the yogi is seated before him at a distance of three inches. ${ }^{50}$ The yogi connects to the Buddha by a ray of light emitted from the white tuft of entwined hair (P. unna) between the eyebrows of the Buddha that reaches the corresponding area of the yogi. ${ }^{51}$ In the following stages, the yogi reverently invites the Buddha to take a seat on the yogi's head and use it as a monastery or a throne. Having taken a seat on the yogi's head (second stage), the Buddha then sinks down to the yogi's navel and waist, thereby covering the upper part of the yogi's body. Therefore, the upper part of the yogi does not exist anymore, because that part is the Buddha (third and fourth stages). In the fifth stage, reckoned as ecstasy meditation (P. jhāna), the essence or power of a buddha (bouddha-dhāt) is acquired by the yogi. At this point, a complete transmutation of the yogi occurs. According to the course book, the yogi should now reflect as follows. The bodily factors are not the yogi's anymore; the yogi's body

48 This kind of non-attached observation was frequently compared with Western scientific procedures by urban Buddhists in Burma (see Brohm 1957:343; King 1990).

49 Among representatives of rationalist modern Buddhism, there is a tendency to view the Buddha as having been an ordinary human being. For instance, Aung San Suu Kyi was criticized by the military government for having described the Buddha in that manner (Gravers 1996:300). In the version of the Buddha legend in the Nidānakathā, the first time the Buddha performed the twin miracle was shortly after he had attained nirvana and enlightenment, with the aim of dispelling the doubts of some gods regarding his status (Jayawickrama 2002:103).

50 In the congregation's manuals, it is not specified which buddha should be visualized here, but some leaders claimed it is Gotama Buddha. However, in one of its ritual texts, seven buddhas are invoked, and these should be visualized in a similar manner.

51 Alternatively, the hair stretches out and reaches the same point between the eyebrows of the yogi. 
has disappeared and the yogi should think thus: "I am the Buddha, the Buddha is me." 52 The yogi's own body has disappeared and he or she has transformed into the living Buddha.

From the fifth stage, the yogi can practice - as an optional interlude - a visualization technique named after a mantra. ${ }^{53}$ This is an auxiliary practice through which the yogi should, in nine stages, gradually transform into a cosmic Buddha seated cross-legged above Mt. Meru, the center of the universe. He or she faces east, with the right knee resting over the southern wall of the universe and the left knee over the northern one, influencing the entire universe with his or her power. Meanwhile, the yogi should recite a mantra up to 108 times to influence the entire world with the glory (bhoun), supernormal power, and the power/essence of the Buddha. ${ }^{54}$ In the sixth stage, the body of the Buddha slowly becomes smaller and smaller. As the body of the Buddha contracts, the various parts of the yogi's own body become visible in a specified order. When the Buddha has shrunken to nine inches high and two inches wide, it is enshrined within the chest of the yogi and occupies the area from the diaphragm to his or her throat. ${ }^{55}$ At this point, the yogis - provided they have vowed to attain buddhahood - can visualize themselves as a world emperor or a king. As before, the practitioners do not merely look like what they visualize themselves to be. Here, the yogi is a world emperor/king, albeit temporarily.

The yogis should conclude the meditation practice by sharing the merit produced from their fulfilling of perfections with all sentient beings. ${ }^{56}$ Traditional ceremonies usually end with that ritual, but here some further rituals of hybrid nature are added. These are concerned with inviting the accomplished esoteric masters and Sekyā Min to perform power-transfer of supernormal powers, receiving this invisible "substance" with outstretched hands and rubbing it onto their bodies. ${ }^{57}$

\section{A Technology for Empowerment, Identity, Power, and Control}

What kinds of felicities - religious (mundane and supermundane), ${ }^{58}$ psychological, emotional, and social - do the members expect to acquire? The rituals for the visualization practice could be described as a multifaceted program for empowerment, and they confirm Turner's thesis regarding status reversals, namely, that "the liminality of the strong is weakness - of the weak, strength" (1977:200). For instance, the practices can provide the members with subjective empowerment by giving them a sense of agency, strength,

52 ngā-thi-pin-hlayin-hpayā:shin, hpayā:shin-thi-pin-hlayin-ngā-hpyic-thi (lit. "I am indeed the Buddha; the Buddha is indeed me").

53 Another auxiliary practice that can be performed from the fifth stage of the recollection of the Buddha is the Dhāt Practice of the World (kambhā-dhät-loup-ngan). In this practice, the yogi can imagine scenarios where he or she, as the Buddha, acts as a compassionate savior of beings from the round of rebirths, or (in the sixth stage) as a world emperor, combatting the anti-Buddhist forces in the world (see Foxeus 2011).

54 The yogi should recite it as many times as possible, but the number must be divisible by nine, an astrologically potent number.

55 In the course book it is stated that the buddha in the yogis' chest will remain there for the rest of their lives.

56 For more on merit-making rituals and transference of merit, see Spiro 1982.

57 These rituals are called $d h \bar{a} t-s \bar{l}$, which can refer to possession, but here should be understood as powertransfer from the accomplished esoteric masters, and dhät-hpyi, "power-filling." A local leader explained this practice to me, and it is prescribed in several of the congregation's books.

58 I agree with Collins' (2006) view of "traditional Buddhism" as comprising both the supermundane and the mundane "felicities," that is, a totality in which nirvana is decentered in the worldview and postponed indefinitely, but recentered in practice (the former does not hold in rationalist modern Buddhism). 
protection, and increased self-esteem. ${ }^{59}$ A few aspects of subjective empowerment will be discussed below: devotionalism, the transformations, the Buddha's presence, strong emotions, expected soteriological effects, supernormal powers, control, and invulnerability. In contrast to the insight meditation movement and its strategy of dissolving the self through realization of the principle of non-self (P. anattā), these practices seem to strengthen the sense of selfhood and produce a grandiose persona, something that might appear especially appealing to lower strata of the dispossessed.

The visualization techniques of the ariy $\bar{a}-w e i z z \bar{a}$ organization require active imagination, and promote a "poetics of imagination and aesthetics" (Flood 2006:29) that draws on the congregation's esoteric Buddhist imaginary in the Jātaka mode. Buddhist devotion is an important dimension of this esoteric version of the recollection of the Buddha, but mainly as part of its preliminary stages. Thereafter the practitioner is transformed into the Buddha, and the dichotomy of subject and object ceases. Hence, the basis of devotion disappears, and the yogis themselves - their very ontological being - transmute into a fully enlightened, powerful, and omniscient Buddha, albeit temporarily. Before this dichotomy dissolves, the devotion should thus reach a climax, as it were. Here, the yogi should first magnify the Buddha - his virtues, supernormal powers, miracles, etc. — and then identify with him — "I am the Buddha, the Buddha is me." What is more, the yogis should visualize themselves as a huge Buddha encompassing the entire universe and influencing it with his or her power. In this way, the body of the yogi is inscribed with the imaginary of the congregation's texts and becomes ritually "entextualized" (Flood 2006:4), embodied and experienced, thereby transforming the yogi into a grandiose subject.

The visualizations should be performed by the members on many occasions, and the merging of their being with the Buddha thereby becomes an intrinsic part of their identity. The Buddha should always be present in the lives of the members. For instance, at the initiation ritual the initiates should supplicate to the Buddha and invite him to use their bodies as a throne, a monastery, or a perfumed chamber, and to remain inside their bodies. The members should always consider the Buddha to be seated on their heads. This is even socially confirmed by the reverential greetings the members make to one another by raising their folded palms to their foreheads. ${ }^{60}$ The greeting is not addressed to the other person per se but to the Buddha seated on the other's head. Moreover, the members should perform the visualization in other kinds of rituals. For instance, at the annual ceremony in 2007, the leader exhorted the participants to contemplate the nine virtues of the Buddha and practice the fifth stage of the recollection of the Buddha. In that stage, he explained, the yogis' bodies have transformed into the Buddha. They are the Buddha; their hands are not their hands, but the Buddha's; their heads are not their own heads, but the Buddha's; their faces are not their own, but the Buddha's. When reciting suttas, it is not they who recite them but the Buddha. However, those who were unable to perform such visualizations could instead visualize the Buddha seated within their chest (as in the sixth stage) or on a throne in front of them (as in the first stage) reciting the suttas.

Since a small Buddha is assumed to be enshrined in the chests of the members, they are turned into a kind of living pagodas of flesh and blood, and they should therefore regard

59 For more on empowerment, see Weissberg 1999:26-29. Moreover, through initiation, the members receive a ritual authorization or empowerment and have thereby acquired a socially confirmed qualification to perform these practices.

60 Traditionally, reverential greetings are considered appropriate towards the Five Eternities (Buddha, Dhamma, Sangha, parents, and teachers). 
themselves as exceedingly pure people. All this gives the members a sense of being special and extraordinary, which is an important social marker in relation to other groups in society. To fully understand the attraction of membership, we need to consider the sense of empowerment that can be enjoyed by, for instance, a peasant, a bus driver, or any woman when they temporarily transform themselves into a powerful and omniscient Buddha.

In Theravādin devotionalism, the distinction between the devotee and the object of devotion is usually maintained, but in the ariy $\bar{a}-w e i z z \bar{a}$ organization that boundary is thus dissolved. Some Burmese people would consider these visualization practices to be shocking and disrespectful - as a kind of lese-majesty in regards to the Buddha or the breaking of a taboo. For this reason, it would be difficult - given the sacrilege that such an action amounts to in Burmese Buddhism - to imagine a more thrilling and empowering experience for the members. Hence, in the ariy $\bar{a}$-weizza $\bar{a}$ organization, not only is the boundary between the monks and laity blurred but also the one between ordinary humans and the Buddha. The antinomian nature of this practice might partly explain why the founder wrote that the first stage of buddhānussati is exoteric while the remaining stages are "secret" (hlyo-hwek). Burmese Buddhists may find the first stage acceptable but not the other ones in which the yogi gradually fuses with the Buddha.

A further facet of the devotionalism is concerned with strong emotions. During the practice, the yogi can experience various kinds of piti, "joy," which increase in intensity. The buddha-piti, a thrilling sensation of joy, is the most important of these among members, and many I met spoke about it. ${ }^{61}$ During the annual ceremony in 2007 , a local leader explained to the participants that this joy is like the pitti on which the brahma gods feed, and they do not need any food but this joy. The members are therefore just like brahma gods, he explained. This notion of feeding on joy again reinforces the sense of empowerment these visualization techniques may provide to the members.

Furthermore, these practices are intended for soteriological aims. The visualizations and transformations are considered powerful and efficacious; that is, such mental acts are performative and have soteriological effects (cf. Flood 2006: 4, 109). In other words, while performing these visualizations the members regard themselves as doing something that improves their lives. For instance, it is said that the practitioners will acquire - amongst other felicities - some power or essence of the Buddha (bouddha-dhatt) which will enable them to make progress on the path to buddhahood. ${ }^{62}$ The more the yogis practices the recollection of the Buddha, the more they will gradually resemble a buddha because of the powerful Buddha seated within their chest.

In contrast to insight meditation, this practice is intended for acquiring a diversity of mundane supernormal powers and potencies, ${ }^{63}$ something that is illustrated by the yogi's transformation into the most powerful political figure of the royal imaginary, namely, the Buddhist world emperor. Having transformed into such a king in the sixth stage, a local leader explained, the yogi has acquired supernormal powers by means of which he can

61 The concept seems to be an innovation of this congregation and appears to refer to a thrilling sensation aroused by not only being in the Buddha's proximity but also transforming into him.

62 This is a kind of supernormal power (dago).

63 Supernormal powers can be obtained through the members' own practice, power-transfer from the accomplished esoteric masters, and the initiation rituals. The most important power, a local leader explained to me in January 2007, is the supernormal mind-power of the accomplished esoteric masters (P. manomayiddhi-vijjādhara). This is a wish-fulfilling power, and a power by means of which it is considered possible to send out mind-projections and thereby be present in two places at the same time. 
control (asou-ya $)$ the five elements and can influence everything. In this state the yogi can rule over the entire universe and issue authoritative commands to all the beings. ${ }^{64}$ At the same time, these two personages - the Buddha and the Buddhist world emperor, the two wheels of Dhamma, the embodiments of the power to penetrate, understand, and preach the Dhamma (P. dhamma-cakka) and the power to command with authority (P. $\bar{a} n \bar{a}-c a k k a)$, respectively epitomize the two ideals that the members of the ariy $\bar{a}$-weizz $\bar{a}$ organization should emulate and seek to realize in their own soteriological careers. ${ }^{65}$

The visualizations can also endow the practitioner with invulnerability, thereby giving the members a sense of being safe and protected. For instance, one member explained that when he was badly ill from a snakebite, a leader told him to visualize himself as Sekyā Min (the founder), the world emperor, and thereby transform into him. The member claimed to have been cured in that manner. A military officer who is a member of the congregation explained that he had fought many battles in the jungles in the border areas and often had visualized himself as Sekyā Min. He thereby escaped the enemy's bullets which he could hear whizzing about his ears. Visualizing and transforming himself in this manner protected him and made him invulnerable to gunfire, he explained. Having been instructed by the founder, the military officer even visualized a bus as the Buddha, thereby transforming the bus into a protective shield when the enemy fired at it. ${ }^{66}$

The practitioners of insight meditation, following a more individualistic social paradigm, cannot rely on anyone else for success in their practice - an approach that accords with the canonical texts, e.g., "Do ye abide, brethren, islands unto yourselves, refuges unto yourselves: taking refuge in none other ...." ${ }^{67}$ By contrast, the practitioners on the esoteric path depend on the accomplished esoteric masters and ritual procedures - or "sacraments" - mediated by the congregation to attain success. ${ }^{68}$ This combination of one's own power and other's power, as well as dependence on a kind of sacraments distributed by a hierarchy of local leaders subordinated to the founder, entails that practitioners depend on others and must be members of the congregation to make soteriological progress. They must thus be part of a community requiring a corporative form of social organization and having shared values and views of Buddhism.

64 However, the leader explained in January 2007, this practice is only intended for those who have embarked on the path to buddhahood, and to acquire the aforementioned powers the yogi must practice this meditation many times.

65 For more on the concept of the two wheels of Dhamma, see Collins 2006:470-476. It should be noted that $\bar{a} n \bar{a}$ is a Buddhist concept of power whose source is religious merit accumulated in previous lives. It is a "power to compel others to obey," and it is linked to authoritarianism (Rozenberg 2009:25). It is thought that the members of the ariy $\bar{a}$-weizzā organization can acquire this power to command others from the ritual technology and power-transfer.

66 In Burma and other countries in Southeast Asia, practices conferring invulnerability usually include yantras (in, sama) inscribed with syllables or numbers (see Patton 2012), tattoos with motifs symbolically related to Buddhism, alchemical balls, etc. By contrast, the ariyā-weizzā organization tends to "Buddhicize" means for acquiring invulnerability in accordance with the ariya discourse.

67 As stated in Attadipa Sutta (Woodward 1954:37).

68 In the ariya $\bar{a}$-weizz $\bar{a}$ organization, initiation is regarded as a prerequisite for receiving support and powertransfer from the accomplished esoteric masters. Through the initiation rituals, a bond is established between the members and the aforementioned masters. Moreover, the congregation distributes — by means of rituals - certain substances that are saturated with potency and are considered to have soteriological effects (becoming an accomplished esoteric master and attaining enlightenment and nirvana). The majority of the esoteric congregations require initiation before providing access to their teachings and practices, but this is not the case with the exoteric insight meditation centers. 


\section{Conclusion}

The ariy $\bar{a}$-weizza $\bar{a}$ organization, like the insight meditation movement, has outlined a complete soteriological program for the attainment of enlightenment and nirvana. What the two have in common is the view that Burmese Buddhists - the laity as well as monks - should practice meditation. The respective stances of the two movements could be viewed as rationalism and detachment versus ritualistic devotionalism. While the practitioners of the vipassana movement, imagining Buddhist practice in the Sutta mode, cultivate a rational, dry, detached, non-emotional, and observational mode, envisioned as a "scientific" mode of seeing "things as they are," the members of the ariy $\bar{a}-w e i z z \bar{a}$ organization, imagining Buddhist practice in the Jätaka mode, cultivate a devotional and emotional attitude toward the Buddha. The latter favors a poetic and aesthetic imagination that draws on the narrative, cosmological, and miraculous dimension of Buddhism. Moreover, it implies a far longer time-frame than what is the case in the vipassana movement. The Buddha is not - as in the vipassana movement - viewed as just an exemplary teacher, who is absent in the here and now and represented by the meditation teacher, but is visualized as a living being who silently displays buddhahood merely by performing miracles, as it were.

In fact, the ariyā-weizz $\bar{a}$ organization's visualization techniques could be said to represent a reversal of the main strategy in the mental culture of the insight meditation movement. While the dominant idiom of meditation in the latter is detachment, "this is not I; this does not belong to me; this is not mine," $" 69$ the ariya $\bar{a}$-weizzā organization's version of the recollection of the Buddha culminates in the insight, "I am the Buddha, the Buddha is me." It is tempting to read this flamboyant self-affirmation as a kind of provocation addressed to proponents of the insight meditation movement.

The ariy $\bar{a}$-weizz $\bar{a}$ organization's brand of "authentic" Buddhism could be interpreted as a response to, and implicit criticism of, not merely the rationalism of the vipassana movement but also some of the practices of the esoteric Gandhära congregations. Moreover, like the vipassan $\bar{a}$ movement, the congregation disapproved of the traditional lay Buddhism for its alleged passivity and ignorance. Presenting its tenets and practices as a vehicle for preserving the authentic aristocratic Buddhism, the congregation's version of Buddhism could be described as an emphasis of the Jātaka mode of practice framed by a royal-esoteric Buddhist imaginary. In its quest for respectability, authority, and authenticity, the congregation negotiated the boundaries of its own version of authentic Buddhism. Assimilating to a great extent the dominant ariya discourse on normative and authentic Buddhism in postcolonial Burma and rejecting some esoteric elements, the congregation could nevertheless retain some esoteric notions and practices derived from local traditions by remolding, "purifying," and "Buddhifying" them, thereby presenting itself as being on par with the vipassana movement.

On a discursive level, the congregation's concentration meditation intersects with a larger complex of notions and practices having an elective affinity with a Buddhist authoritarian political model. The latter is part of a royal imaginary and is reproduced at various levels of the esoteric congregation's tenets, practices, social organization, etc. ${ }^{70}$ The rich repertoire of

${ }^{69}$ This is part of the realization of the teaching on non-self (P. anattā).

70 It must be underscored that this observation is only concerned with the official discourse of the congregation. It is not a statement of the members' political preferences. During the time of my fieldwork (2005-2008), Burma was ruled by a military dictatorship, and it would have been ethically irresponsible to ask members about their political views. 
This is the version of the article that was accepted for publication. It was published in 2016 in Numen 63: 411-445.

opportunities for status reversals offered by the congregation - including the various facets of a royal identity, as well as a bodhisatta identity and a Buddha identity, which can be acquired by the members transforming them from humble devotees of the Buddha into the Buddha himself or a king, etc. — provides the members with potent sources of empowerment and identity.

As noted above, there have been some tensions between representatives of rational modern Buddhism and the esoteric movements, with the former frequently criticizing and disparaging the latter. In postcolonial Burma, the esoteric modern Buddhism should be understood as a counter-discourse in relation to the dominant insight meditation movement to which it was subordinated. The two movements could be said to represent a polarization of the religious field: towards supernaturalism, the miraculous, and the inclusion of traditional elements, on the one hand, and towards rationalism, empiricism, and a de-emphasizing of local traditions, on the other. They thus represent two ways of constructing a local and national identity. This quest for identity emerged in response to colonization, modernization, and - after independence - nation-building projects and further modernization, all of which gave rise to a modern crisis of authority that undermined traditional certainties. These factors contributed in various degrees to the rise of two distinct movements of modern lay Buddhism in Burma, each representing alternative forms of modernity.

However, it is not simply the case that practitioners of esoteric modern Buddhism are "traditionalists." While the insight meditation movement sought to eliminate everything deemed to be later accretions associated with the local tradition, etc., and mainly ascribed authority to "doctrines" found in a selection of canonical texts (see Houtman1990: 15-16), esoteric modern Buddhism sought to recalibrate, reinterpret, and reaffirm a selection of practices and notions mainly derived from the indigenous Burmese traditions and the commentarial Pāli texts. While there is a stress on universalism in the former, albeit a universalism established by and through Burma, as it were, there is an emphasis on sheer localism in the latter. Proponents of both paths sought to restore and reaffirm what they perceived to be "authentic" or "real" Buddhism, something for which they established more or less well-defined boundaries, and which could serve as a source of individual, local, and national identity. As a solution to the burning issue not only of what is "real" Buddhism but more importantly what it means to be a "true" or "real" Buddhist, the ariy $\bar{a}$-weizz $\bar{a}$ organization seems to have suggested that to be a "real" Buddhist is simply to be the Buddha.

\section{References}

The ariy $\bar{a}$-weizzā organization. 1979 [1341 M.E.]. Shin-tan-tek-sin Thin-tan-gyz [The Great Course on Developing Clarity].

1997 [1957]. Ariyā-weizzā-pațipāt Dhät-tek-sin-kyan [The Treatise on the Development of Dhāt and the Practice of Noble Esoteric Knowledge].

Benavides, Gustavo. 2010. "On the Production of Religious Configurations." Method \& Theory in the Study of Religion 22:239-253.

Braun, Erik Christopher. 2008. "Ledi Sayadaw, Abhidhamma, and the Development of the Modern Insight Meditation Movement in Burma." Ph.D. dissertation. Cambridge, Mass.: Harvard University.

Brohm, John Frank. 1957. "Burmese Religion and the Burmese Buddhist Revival." Ph.D. dissertation. Ithaca, N.Y.: Cornell University. 
This is the version of the article that was accepted for publication. It was published in 2016 in Numen 63: 411-445.

Collins, Steven. 2006 [1998]. Nirvana and Other Buddhist Felicities: Utopias of the Pali Imaginaire. Cambridge: Cambridge University Press.

Cousins, Lance S. 1984. "Samatha-yana and Vipassana-yana." In Gatare Dharmapala, Richard Gombrich, and K. R. Norman (eds.), Buddhist Studies in Honour of Hammalava Saddhātissa, Nugegoda: Hammalava Saddhatissa Felicitation Volume Committee, 56-68.

Crosby, Kate. 2000. "Tantric Theravāda: A Bibliographic Essay on the Writings of François Bizot and Others on the Yogāvacara Tradition." Contemporary Buddhism 1(2):141198.

Eisenstadt, S. N. 2000. "Multiple Modernities.” Daedalus 129(1):1-29.

Ferguson, John P., and E. Michael Mendelson. 1981. "Masters of the Buddhist Occult: The Burmese Weikzas.” In John P. Ferguson (ed.), Essays on Burma, Leiden: Brill, 6280 .

Flood, Gavin. 2006. The Tantric Body: The Secret Tradition of Hindu Religion. London: I. B. Tauris.

Foxeus, Niklas. 2011. "The Buddhist World Emperor's Mission: Millenarian Buddhism in Postcolonial Burma.” Ph.D. dissertation. Stockholm: Stockholm University.

. 2012. "The World Emperor's Battle against the Evil Forces." Journal of Burma Studies 16(2):213-250.

. Forthcoming. "Contemporary Burmese Buddhist Traditions." In Michael Jerryson (ed.), Oxford Handbook of Contemporary Buddhism, New York: Oxford University Press.

Gokhale, Balkrishna Govind. 1981. "Bhakti in Early Buddhism." In Jayant Lele (ed.), Tradition and Modernity in Bhakti Movements, Leiden: E. J. Brill, 16-28.

Gombrich, Richard F. 1998 [1971]. Buddhist Precept and Practice: Traditional Buddhism in the Rural Highlands of Ceylon. Delhi: Motilal Banarsidass.

—, and Gananath Obeyesekere. 1990 [1988]. Buddhism Transformed: Religious Change in Sri Lanka. Delhi: Motilal Banarsidass Publishers.

Gravers, Mikael. 1996. "Questioning Autocracy in Burma: Buddhism between Traditionalism and Modernism." In David Westerlund (ed.), Questioning the Secular State: The Worldwide Resurgence of Religion in Politics, London: Hurst \& Company, 297-322.

— 2012. "Monks, Morality and Military: The Struggle for Moral Power in Burma and Buddhism's Uneasy Relation with Lay Power." Contemporary Buddhism 13(1):1-33.

Hirakawa, Akira. 1993 [1990]. A History of Indian Buddhism: From Śákyamuni to Early Mahāyāna. Paul Groner (ed. and trans.). Delhi: Motilal Banarsidass.

Houtman, Gustaaf. 1990. "Traditions of Buddhist Practice in Burma." Ph.D. dissertation. London: London University.

1999. Mental Culture in Burmese Crisis Politics: Aung San Suu Kyi and the National League for Democracy. Tokyo: Tokyo University of Foreign Studies.

Jackson, Peter. 2012. "Apparitions and Apparatuses: On the Framing and Staging of Religious Events." Method \& Theory in the Study of Religion 24(3):291-300.

Jayawickrama, N. A. (trans.). 2002. The Story of Gotama Buddha: The Nidanna-katha of the Jätakatțakathā. Oxford: The Pali Text Society.

Jordt, Ingrid. 2001. "Mass Lay Meditation and State-Society Relations in Post-Independence Burma." Ph.D. dissertation. Cambridge, Mass.: Harvard University. 
This is the version of the article that was accepted for publication. It was published in 2016 in Numen 63: 411-445.

2007. Burma's Mass Lay Meditation Movement: Buddhism and the Cultural Construction of Power. Athens: Ohio University Press.

Keyes, Charles F., Helen Hardacre, and Laurel Kendall. 1994. "Introduction." In Charles F. Keyes, Laurel Kendall, and Helen Hardacre (eds.), Asian Visions of Authority: Religion and the Modern States of East and Southeast Asia, Honolulu: University of Hawai'i Press, 1-16.

King, Richard. 2002 [1999]. Orientalism and Religion: Postcolonial Theory, India and the "Mystic East." London: Routledge.

King, Winston L. 1990 [1964]. A Thousand Lives Away: Buddhism in Contemporary Burma. Berkeley: Asian Humanities Press.

Kirichenko, Alexey. 2009. "From Thathanadaw to Theravāda Buddhism: Constructions of Religion and Religious Identity in Nineteenth- and Early Twentieth-Century Myanmar." In Thomas David DuBois (ed.), Casting Faiths: Imperialism and the Transformation of Religion in East and Southeast Asia, Hampshire: Palgrave Macmillan, 23-39.

Koenig, William J. 1990. The Burmese Polity, 1752-1819: Politics, Administration, and Social Organization in the Early Kon-baung Period. Ann Arbor: University of Michigan.

Ledi Hsayādaw. 1985 [1898]. "Vijjā-magga-dīpanī." In Ledi Dipani-paung-hkyup, vol. 2, Yangon: Thathana-yay-u-si-htana-pon-hneik-taik.

Lieberman, Victor B. 1984. Burmese Administrative Cycles: Anarchy and Conquest, c. 15801760. Princeton: Princeton University Press.

Lincoln, Bruce. 2006 [2003]. Holy Terrors: Thinking about Religion after September 11. 2nd ed. Chicago: University of Chicago Press.

Lopez, Donald S., Jr. 2002. "Introduction.” In Donald S. Lopez, Jr. (ed.), Modern Buddhism: Readings for the Unenlightened, London: Penguin Books, ix-xliii.

Mahāsi Hsayādaw. 1990. Satipatțhāna Vipassanā. U Pe Thin (trans.). Kandy: Buddhist Publication Society.

Mackenzie, Rory. 2007. New Buddhist Movements in Thailand: Towards an Understanding of Wat Phra Dhammakāya and Santi Asoke. London: Routledge.

Mendelson, Michael. 1960. "Religion and Authority in Modern Burma." The World Today 16:110-118.

. 1961. "A Messianic Buddhist Association in Upper Burma." Bulletin of the School of Oriental and African Studies 24(3):560-580.

Nyanatiloka. 2004 [1946]. Buddhist Dictionary: A Manual of Buddhist Terms and Doctrines. Chiang Mai: Silkworm Books.

Patton, Thomas. 2012. "In Pursuit of the Sorcerer's Power: Sacred Diagrams as Technologies of Potency." Contemporary Buddhism 13(2):213-231.

Perreira, Todd LeRoy. 2012. "Whence Theravāda? The Modern Genealogy of an Ancient Term.” In Peter Skilling, Jason A. Carbine, Claudio Cicuzza, and Santi Padeekham (eds.), How Theravāda is Theravāda: Exploring Buddhist Identities, Chiang Mai: Silkworm Books, 443-571.

Pranke, Patrick. 1995. "On Becoming a Buddhist Wizard." In Donald S. Lopez, Jr. (ed.), Buddhism in Practice, Princeton: Princeton University Press, 343-358.

2011. "On Saints and Wizards: Ideals of Human Perfection and Power in Contemporary Burmese Buddhism." Journal of the International Association of Buddhist Studies 33(1-2):453-488. 
This is the version of the article that was accepted for publication. It was published in 2016 in Numen 63: 411-445.

Rhys Davids, T. W., and William Stede (eds.). 1979 [1921-1925]. The Pali Text Society's Pali-English Dictionary. London: The Pali Text Society.

Rozenberg, Guillaume. 2009. "How 'The Generals' Think: Gustaaf Houtman and the Enigma of the Burmese Military Regime." Aséanie 24:11-31.

- 2010a. Renunciation and Power: The Quest for Sainthood in Contemporary Burma. Jessica L. Hackett (trans.). New Haven: Yale University Southeast Asia Studies.

2010b. Les Immortels: Visages de l'incroyable en Birmanie bouddhiste. Vannes Cedex: Sully.

Ruel, Malcolm. 2002. "Christians as Believers." In Michael Lambek (ed.), A Reader in the Anthropology of Religion, Oxford: Blackwell Publishing, 99-113.

Samuels, Jeffrey. 1997. "The Bodhisattva Ideal in Theravada Buddhist Theory and Practice: A Reevaluation of the Sravaka-Bodhisattva Opposition." Philosophy East and West 47(3):399-415.

Sarkisyanz, Emanuel. 1965. Buddhist Backgrounds of the Burmese Revolution. The Hague: Martinus Nijhoff.

Schober, Juliane. 1988. "The Path to Buddhahood: The Spiritual Mission and Social Organization of Mysticism in Contemporary Burma." Crossroads 4(1):13-30.

- 1989. "Paths to Enlightenment: Theravada Buddhism in Upper Burma." Ph.D. dissertation. Urbana-Champaign: University of Illinois.

. 1995. "The Theravāda Buddhist Engagement with Modernity in Southeast Asia: Whither the Social Paradigm of the Galactic Polity." Journal of Southeast Asian Studies 26(2):307-325.

- 2011. Modern Buddhist Conjunctures in Myanmar: Cultural Narratives, Colonial Legacies, and Civil Society. Honolulu: University of Hawai'i Press.

Skilling, Peter. 2012. "King Rāma I and Wat Chetuphon: the Buddha-śāsanā in Early Bangkok." In Peter Skilling, Jason A. Carbine, Claudio Cicuzza, and Santi Padeekham (eds.), How Theravāda is Theravāda: Exploring Buddhist Identities, Chiang Mai: Silkworm Books, 297-352.

Spiro, Melford E. 1982 [1970]. Buddhism and Society: A Great Tradition and its Burmese Vicissitudes. Berkeley: University of California Press.

1996 [1967]. Burmese Supernaturalism. Expanded ed. New Brunswick: Transaction Publishers.

Swearer, Donald K. 1995. "The Way to Meditation." In Donald S. Lopez, Jr. (ed.), Buddhism in Practice, Princeton: Princeton University Press, 207-215.

Tosa, Keiko. 1996. "A Consideration of Weikza Belief in Burma: the Meaning of làwki and làwkoktara for the gaing." Mizokugaku Kenkyu 61:215-242.

Turner, Alicia. 2009. Buddhism, Colonialism and the Boundaries of Religion: Theravada Buddhism in Burma, 1885-1920. Ph.D. dissertation. Chicago: University of Chicago.

Turner, Victor. 1977 [1969]. The Ritual Process: Structure and Anti-Structure. Ithaca, N.Y.: Cornell University Press.

Weissberg, Robert. 1999. The Politics of Empowerment. Westport: Praeger.

Woodward, F. L. (trans.). 1954 [1925]. The Book of Kindred Sayings (Samyutta-Nikāya) or Grouped Suttas. Part III. London: The Pali Text Society. 